\title{
Soman hydrolysis catalysed by hypochlorite ions
}

\author{
Mengxue $\mathrm{Xu}^{1}$, Hongpeng Zhang ${ }^{1}$, Haiyan Zhu ${ }^{1}$, Lianyuan Wang $^{1 *}$, Chaohua Zhou ${ }^{1 *}$ \\ ${ }^{1}$ Institute of Chemical Defense (Army), Beijing, 102205, China
}

\begin{abstract}
Sarin (GB) and soman (GD)are severely toxic nerve agents that react slowly in water, resulting in long-term poisoning of the water and a serious threat to personnel. Some ions can catalyse GB and GD hydrolysis in water; the relevant research for GB is detailed, whereas that for GD is relatively less so. In this paper, GD hydrolysis catalysed by hypochlorite $\left(\mathrm{ClO}^{-}\right)$ions was studied via kinetic experiments. A fluoriteion-specific electrode was used to monitor $\mathrm{F}^{-}$ions produced, allowing the rate constant and half-life of the GD hydrolysis to be calculated. The results showed that $\mathrm{ClO}^{-}$ions promote GD hydrolysis well; the higher the concentration of $\mathrm{ClO}^{-}$, the faster the GD was hydrolysed. In $\mathrm{NaClO}$ solution at $\mathrm{pH} 8.0$ with $3.22 \times 10^{-3} \mathrm{M}$ $\mathrm{ClO}^{-}$ions, the half-life of GD hydrolysis was $82.5 \mathrm{~s}$, about 875 times shorter than that in water at $\mathrm{pH} 8.0$. The rate constant for catalysis of GD hydrolysis by $\mathrm{ClO}^{-}$ions $\left(k_{\mathrm{ClO}}{ }^{-}\right)$was $2.6 \mathrm{M}^{-1} \mathrm{~s}^{-1}$, about one quarter the value of $\mathrm{KOH}^{-}$but over 1500 times greater than $k_{\mathrm{B}}$ and $k_{\mathrm{PO}_{4}^{3-}}$, with B representing $N$-2-hydroxyethylpiperazine- $N^{\prime}-$

2-ethanesulfonic acid present as a free base; this result indicated that $\mathrm{ClO}^{-}$ions catalyse GD hydrolysis well.
\end{abstract}

\section{Introduction}

Sarin (GB) and soman (GD) are soluble in water, but they react slowly in water with a mid-range $\mathrm{pH}$ value, causing long-term poisoning [1]. The spontaneous hydrolysis rate constant of GB determined in water at $\mathrm{pH} 7$ is $2 \times 10^{-4}$ $\min ^{-1}$ [2], and the half-life $\left(t_{1 / 2}\right)$ is $3465.7 \mathrm{~min}$. Hydroxide $\left(\mathrm{OH}^{-}\right)$ions can catalyse the hydrolysis of GB through a nucleophilic reaction. The GB hydrolysis rate constants in water at $\mathrm{pH} 8$ and $\mathrm{pH} 9$ are approximately $2 \times 10^{-3} \mathrm{~min}^{-1}$ and $2 \times 10^{-2} \mathrm{~min}^{-1}$, respectively [2]. Therefore, alkaline decontamination has been widely used to detoxify GB [3][4]. Detailed studies showed that other ions can catalyse hydrolysis of GB as well, and the speed of GB hydrolyses catalysed by hypochlorite ions [2], amines [5], metal ions [6], catechols [7] and phenols [8] were obviously faster than that in water at a similar $\mathrm{pH}$ value.

The rate of reaction for GD is slower than that for GB. For instance, the $t_{1 / 2}$ of GD hydrolysis in water at $\mathrm{pH} 8$ is $1200 \mathrm{~min}$, about four times longer than that of GB hydrolysis. This is probably because of the greater steric hindrance of the pinacolyl group on GD relative to that of the isopropyl group on GB [9].<smiles>CC(C)OP(C)(=O)F</smiles>

GB

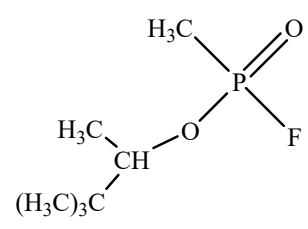

GD
Studies on GD hydrolysis catalysed by ions are less available than those for GB. Albizo and Ward studied GD hydrolysis catalysed by $N$-2-hydroxyethylpiperazine- $N$ '- 2-ethanesulfonic acid (HEPES) and determined that the rate of hydrolysis of GD was linearly related to the concentration of HEPES present as free base (B) in the solution [10]. Creasy found that the reactivity of GB and GD increased in phosphate buffer at $\mathrm{pH} 7$ relative to those in distilled water or acetate buffer [9]. Other than this, there have been few related studies in the past two decades. However, GD is more acutely toxic than GB and there is no specific medicine for poisoning caused by it, so it is necessary to study the rapid decontamination of GD.

In this paper, kinetic experiments were performed to research GD hydrolysis rates in reaction solutions with different concentrations of $\mathrm{ClO}^{-}$ions, with a fluorite-ionspecific electrode being used to monitor the $\mathrm{F}^{-}$ions produced from GD hydrolysis. The impacts of $\mathrm{ClO}^{-}$ions and other factors on GD hydrolysis were studied, the rate constants and half-lives of GD hydrolysis in different reaction solutions were calculated and the catalysing effect of $\mathrm{ClO}^{-}$ions on GD hydrolysis was compared with those of other ions.

\section{Experimental section}

\subsection{Chemicals}

GD had a purity of $>95 \%$. Because of its high toxicity, it was handled only by well-trained personnel using appropriate safety procedures.

$\mathrm{NaClO}$ solution was supplied by Beijing Agents Inc. The available chlorine ([Cl]) was determined to be about $28000 \mathrm{mg} \mathrm{L}^{-1}$ by an available chlorine rapid determination instrument (Q-CL501C), and the $\mathrm{pH}$ value was measured to be 12.6 with a commercial laboratory

*Corresponding author's e-mail: wangly09@sina.com; fhzch@163.com 
$\mathrm{pH} / \mathrm{ORP}$ /temperature tester (HI2221 HANNA). $\mathrm{NaH}_{2} \mathrm{PO}_{4}$ and $\mathrm{Na}_{2} \mathrm{HPO}_{4}$ were obtained from Beijing Agents Inc.

A phosphate buffer solution with a composition of 0.2 $\mathrm{M} \mathrm{PO}_{4}{ }^{3-}$ was prepared from a mixture of $0.2 \mathrm{M} \mathrm{NaH}_{2} \mathrm{PO}_{4}$ $(5.3 \mathrm{~mL})$ and $0.2 \mathrm{M} \mathrm{Na}_{2} \mathrm{HPO}_{4}(94.7 \mathrm{~mL})$, and the $\mathrm{pH}$ value was measured to be 8.0. Phosphate buffer solutions containing $\mathrm{ClO}^{-}$ions in different concentrations were prepared by adding different volumes of $\mathrm{NaClO}$ solution. The $\mathrm{ClO}^{-}$concentration $\left(\mathrm{C}_{\mathrm{ClO}^{-}}\right.$or $\left.\left[\mathrm{ClO}^{-}\right]\right)$could be calculated from equation (1), in which $\left[\mathrm{H}^{+}\right]$is the $\mathrm{H}^{+}$ concentration and $K_{\mathrm{a}}$ is the acid dissociation constant of hypochlorous acid $(\mathrm{HClO})$ at $25{ }^{\circ} \mathrm{C}$, which is $4.0 \times 10^{-8}$ $\left(p K_{\mathrm{a}}=7.4\right)$ [11]. The $\mathrm{C}_{\mathrm{ClO}}{ }^{-}$and $\mathrm{pH}$ values of the different phosphate buffer solutions are displayed in Table 1.

$$
\left[\mathrm{ClO}^{-}\right]=\frac{\mathrm{K}_{a}[\mathrm{Cl}]}{\left[\mathrm{H}^{+}\right]+\mathrm{K}_{a}}
$$

Table 1. $\mathrm{ClO}^{-}$concentration $\left(\mathrm{ClO}_{\mathrm{ClO}}^{-}\right)$and $\mathrm{pH}$ values of phosphate buffer solutions

\begin{tabular}{ccccc}
\hline$V_{\text {phos }}(\mathrm{mL})$ & $V_{\mathrm{NaClO}}(\mathrm{mL})$ & {$[\mathrm{Cl}]\left(\mathrm{mg} \mathrm{L}^{-1}\right)$} & $\mathrm{C}_{\mathrm{ClO}}^{-}(\mathrm{M})$ & $\mathrm{pH}$ value \\
\hline \multirow{3}{*}{30} & 0 & 0 & 0 & 8.0 \\
& 0.04 & 30 & $3.22 \times 10^{-4}$ & 8.0 \\
& 0.36 & 300 & $3.22 \times 10^{-3}$ & 8.0 \\
\hline
\end{tabular}

$V_{\text {phos }}$ and $V_{\mathrm{NaClO}}$ were the volume of phosphate buffer and $\mathrm{NaClO}$ solution, respectively.

Solid $\mathrm{NH}_{4} \mathrm{Cl}$ (supplied by Beijing Agents Inc.) was added to $\mathrm{NaClO}$ solution with a ratio of 1:100 (wt:vol) to decrease the $\mathrm{pH}$ value of the $\mathrm{NaClO}$ solution from 12 to approximately 8 . The reaction was as follows:

$$
\mathrm{NaClO}+\mathrm{NH}_{4} \mathrm{Cl} \rightarrow \mathrm{NH}_{3} \uparrow+\mathrm{NaCl}+\mathrm{HClO}
$$

This showed that the reaction did not produce new ions in $\mathrm{NaClO}$ solution and resulted in a $C_{\mathrm{ClO}^{-}}$decrease. A series of $\mathrm{NaClO}$ solutions with different $\mathrm{C}_{\mathrm{ClO}}{ }^{-}$values were prepared by mixing the $\mathrm{pH} 8 \mathrm{NaClO}$ solution and water at different volume ratios. It was found that the $\mathrm{pH}$ values of these $\mathrm{NaClO}$ solutions were all about 8 (Table 2).

Table 2. $\mathrm{ClO}^{-}$concentration $\left(\mathrm{ClO}^{-}\right)$and $\mathrm{pH}$ value of $\mathrm{NaClO}$ solutions

\begin{tabular}{cccc}
\hline Solution & {$[\mathrm{Cl}]\left(\mathrm{mg} \mathrm{L}^{-1}\right)$} & $C_{\mathrm{ClO}}^{-}(\mathrm{M})$ & $\mathrm{pH}$ value \\
\hline & 300 & $3.22 \times 10^{-3}$ & 8.0 \\
& 1500 & $1.61 \times 10^{-2}$ & 8.1 \\
NaClO solutions with & 3600 & $3.86 \times 10^{-2}$ & 8.1 \\
different $C_{\mathrm{ClO}}^{-}$values & 6600 & $7.08 \times 10^{-2}$ & 8.2 \\
& 10000 & $1.07 \times 10^{-1}$ & 8.2 \\
\hline
\end{tabular}

\subsection{Methods}

A fluorite-ion-specific electrode purchased from METTLER TOLEDO was used for real-time monitoring of the concentration of $\mathrm{F}^{-}$produced by GD hydrolysis in solution. The GD hydrolysis ratio $\left(R_{\mathrm{GD}}, \%\right)$ could then be calculated and the hydrolysis kinetic curve could be drawn. Kinetic experiments were carried in a thermostatic environment $\left(25 \pm 1^{\circ} \mathrm{C}\right)$.

GD $(23 \mu \mathrm{L}$, about $23 \mathrm{mg})$ was added to phosphate buffer solutions or $\mathrm{NaClO}$ solutions with different $C_{\mathrm{ClO}}{ }^{-}$ values $(30 \mathrm{ml})$, resulting in a GD concentration of about $4.21 \times 10^{-3} \mathrm{M}$. Magnetic stirring was used to maintain a stable mass-transfer process. Changes in $\mathrm{pH}$ value and temperature were monitored inline with a commercial laboratory $\mathrm{pH} / \mathrm{ORP} /$ temperature tester (HI2221 HANNA). GD was thought to have been completely hydrolysed when the $\mathrm{F}^{-}$concentration changed by less than $0.1 \mathrm{mg} \mathrm{L}^{-1}$ within $15 \mathrm{~min}$.

The $R_{\mathrm{GD}}$ value could be calculated from equation (2), in which $C_{\mathrm{GD}}\left(\mathrm{mg} \mathrm{L}^{-1}\right)$ was the GD concentration when time was $t(\mathrm{~s})$ and $C_{\mathrm{GD}, 0}\left(\mathrm{mg} \mathrm{L}^{-1}\right)$ was the total GD concentration added into the reaction solution.

$$
R_{G D}=\left(1-\frac{C_{G D}}{C_{G D, 0}}\right) \times 100 \%
$$

Because the $\mathrm{pH}$ value in the reaction solutions and the temperature were controlled during the experiments, GD hydrolysis was considered to follow first-order kinetics. The first-order kinetic rate constant of GD hydrolysis $\left(k_{1}\right.$, $\mathrm{s}^{-1}$ ) could be calculated from equation (3).

$$
C_{G D}=C_{G D, 0} e^{-k_{1} t}
$$

The $\mathrm{F}^{-}$concentration at the time that GD was hydrolysed completely was recorded as $C_{\mathrm{F}}^{-}$, the $\mathrm{F}^{-}$ concentration during GD hydrolysis was $C_{\mathrm{F}}{ }^{-}, t$, and the $\mathrm{F}^{-}$ concentration at the moment that GD was added into the reaction solution was $C_{\mathrm{F}}^{-}, 0$, which is regarded as the background $\mathrm{F}^{-}$concentration. This led to equations (4) and (5).

$$
\begin{aligned}
R_{G D} & =\frac{C_{F^{-}, t}-C_{F^{-}, 0}}{C_{F^{-}}-C_{F^{-}, 0}} \times 100 \% \\
k_{1} t & =-\ln \left(1-\frac{C_{F^{-}, \mathrm{t}}-C_{F^{-}, 0}}{C_{F^{-}}-C_{F^{-}, 0}}\right)
\end{aligned}
$$

The half-life of GD hydrolysis $\left(t_{1 / 2}, s\right)$ could be calculated according to equation (6). 


$$
t_{1 / 2}=\frac{\ln 2}{k_{1}}
$$

\section{Results and discussion}

Initially, experiments were performed to study GD hydrolysis in phosphate buffer solutions with different
$C_{\mathrm{ClO}^{-}}{ }^{-}$values, and the results are shown in Table 3. Compared with that of GD hydrolysis in $\mathrm{NaOH}$ solution at $\mathrm{pH} 8.0$, the $k_{1}$ of GD was relatively higher in phosphate buffer solution at a similar $\mathrm{pH}$ value. When $\mathrm{ClO}^{-}$was introduced into the phosphate buffer solution, the speed of GD hydrolysis was further accelerated with the increase in $C_{\mathrm{ClO}}{ }^{-}$. Therefore, it could be concluded that $\mathrm{ClO}^{-}$at a relatively low concentration could promote GD hydrolysis to some extent.

Table 3. GD hydrolysis in $\mathrm{NaOH}$ solution and phosphate buffer solutions with different $\mathrm{ClO}^{-}$concentrations $\left(25 \pm 1^{\circ} \mathrm{C}\right)$

\begin{tabular}{llllll}
\hline Reaction solution & $\mathrm{pH}$ & $\begin{array}{l}\text { Major ion in reaction solution } \\
\text { and its concentration }(\mathrm{M})\end{array}$ & $C_{\mathrm{GD}, 0}(\mathrm{M})$ & $k_{1}\left(\mathrm{~s}^{-1}\right)$ & $t_{1 / 2}(\mathrm{~s})$ \\
\hline $\begin{array}{l}\mathrm{NaOH} \\
\text { phosphate buffer }\end{array}$ & 8.0 & $\mathrm{OH}^{-}, 1.00 \times 10^{-6}$ & & $9.6 \times 10^{-6}$ & 72000.0 \\
$\mathrm{PO}_{4}^{3-}, 2.00 \times 10^{-1}$ & & $6.0 \times 10^{-4}$ & 1155.3 \\
$\begin{array}{l}\text { phosphate buffer }+ \\
\text { NaClO }\end{array}$ & 8.0 & $\begin{array}{l}\mathrm{PO}_{4}^{3-}, 2.00 \times 10^{-1} ; \\
\mathrm{ClO}^{-}, 3.22 \times 10^{-4}\end{array}$ & $4.21 \times 10^{-3}$ & $1.3 \times 10^{-3}$ & 553.2 \\
$\mathrm{PO}^{3-}, 2.00 \times 10^{-1} ;$ & & $1.0 \times 10^{-2}$ & 69.3 \\
$\mathrm{ClO}^{-}, 3.22 \times 10^{-3}$ & 8.0 & & & \\
\hline
\end{tabular}

Changes in the $\mathrm{pH}$ value during GD hydrolysis in the reaction solutions were monitored and corresponded to the GD hydrolysis rate (Figure 1). The results showed that the $\mathrm{pH}$ value hardly decreased during GD hydrolysis in each reaction solution and the final $\mathrm{pH}$ values of the solutions were very similar. Consequently, it could be concluded that the $\mathrm{ClO}^{-}$ions did not accelerate GD hydrolysis by affecting the $\mathrm{pH}$ value of the reaction solution.
Temperature fluctuations during GD hydrolysis in different solutions were also monitored. It was found that the change in the temperature of the reaction solutions was within $0.1^{\circ} \mathrm{C}$, so temperature fluctuation was not a factor in promoting GD hydrolysis in our experiments. In conclusion, it should be the presence of the $\mathrm{ClO}^{-}$ions that is a critical factor for accelerating GD hydrolysis.

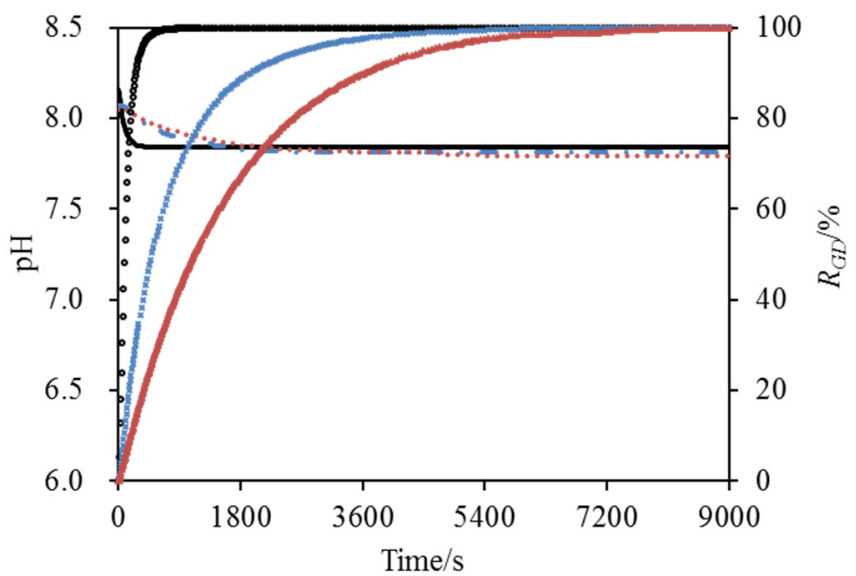

$\mathrm{pH}$

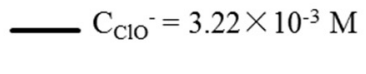$$
-\cdots \mathrm{C}_{\mathrm{ClO}}{ }^{-}=3.22 \times 10^{-4} \mathrm{M}
$$$$
\text { …. } \mathrm{C}_{\mathrm{ClO}}{ }^{-}=0 \mathrm{M}
$$$$
R_{G D} \quad \text { } \quad \mathrm{C}_{\mathrm{ClO}}{ }^{-}=3.22 \times 10^{-3} \mathrm{M}
$$$$
\text { * } \mathrm{C}_{\mathrm{ClO}}{ }^{-}=3.22 \times 10^{-4} \mathrm{M}
$$$$
\Delta \mathrm{C}_{\mathrm{ClO}^{-}}=0 \mathrm{M}
$$

Figure 1 Change in $\mathrm{pH}$ value and hydrolysis rate of $\mathrm{GD}\left(R_{\mathrm{GD}}\right)$ in phosphate buffer solutions with different $C_{\mathrm{ClO}}$ values $\left(C_{\mathrm{GD}, 0}\right.$ was $\left.4.21 \times 10^{-3} \mathrm{M}\right)$

GD hydrolysis in $\mathrm{NaClO}$ solutions with $\mathrm{ClO}^{-}$ions at different concentrations was then studied through the kinetic experiments mentioned in the Experimental Section, and the results were compared with those for $\mathrm{NaOH}$ solutions. Changes in $\mathrm{pH}$ value were monitored (Figure 2), hydrolysis ratios of GD were calculated (Figure 3), and the first-order kinetic rate constants $\left(k_{1}\right)$ and half-lives $\left(t_{1 / 2}\right)$ of GD hydrolysis were calculated and are shown in Table 4.

Fig 2 shows that the $\mathrm{pH}$ values decreased slightly except in the $\mathrm{NaClO}$ solution with $3.22 \times 10^{-3} \mathrm{M} \mathrm{C}_{\mathrm{ClO}}^{-}$, which might because there is not sufficient capacity to neutralise the acid produced by GD hydrolysis. However, other solutions with higher $C_{\mathrm{ClO}}{ }^{-}$values had sufficient neutralising capacity, so the $\mathrm{pH}$ values of these solutions remained almost unchanged during GD hydrolysis.

It can be seen from Fig. 3 and Table 4 that the speed of GD hydrolysis was obviously promoted by $\mathrm{ClO}^{-}$ions in $\mathrm{NaClO}$ solutions relative to that in $\mathrm{NaOH}$ solution at a similar $\mathrm{pH}$ value. In $\mathrm{NaClO}$ solution at $\mathrm{pH} 8.0$ with $3.22 \times 10^{-3} \mathrm{M} \mathrm{C}_{\mathrm{ClO}}{ }^{-}$, the first-order rate constant $k_{1}$ of GD hydrolysis was $8.4 \times 10^{-3} \mathrm{~s}^{-1}$, about 4230 times larger than that in $\mathrm{NaOH}$ solution at $\mathrm{pH} 8.0$. The higher the $C_{\mathrm{ClO}}{ }^{-}$, the faster the speed of GD hydrolysis (Figure 3, Table 4), but the promoting effect of $\mathrm{ClO}^{-}$ions on GD hydrolysis tended to be gradual (Figure 4). 


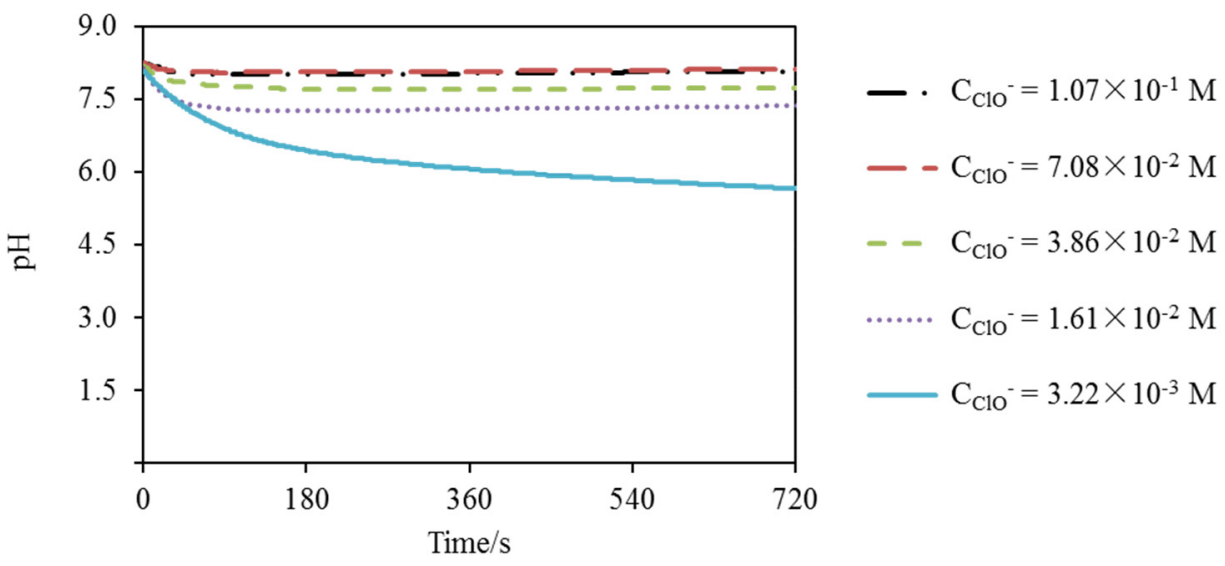

Figure 2 Change in $\mathrm{pH}$ value during $\mathrm{GD}$ hydrolysis in $\mathrm{NaClO}$ solutions with different $C_{\mathrm{ClO}}{ }^{-}$values $\left(C_{\mathrm{GD}, 0}\right.$ was $4.21 \times 10^{-3} \mathrm{M}$ )

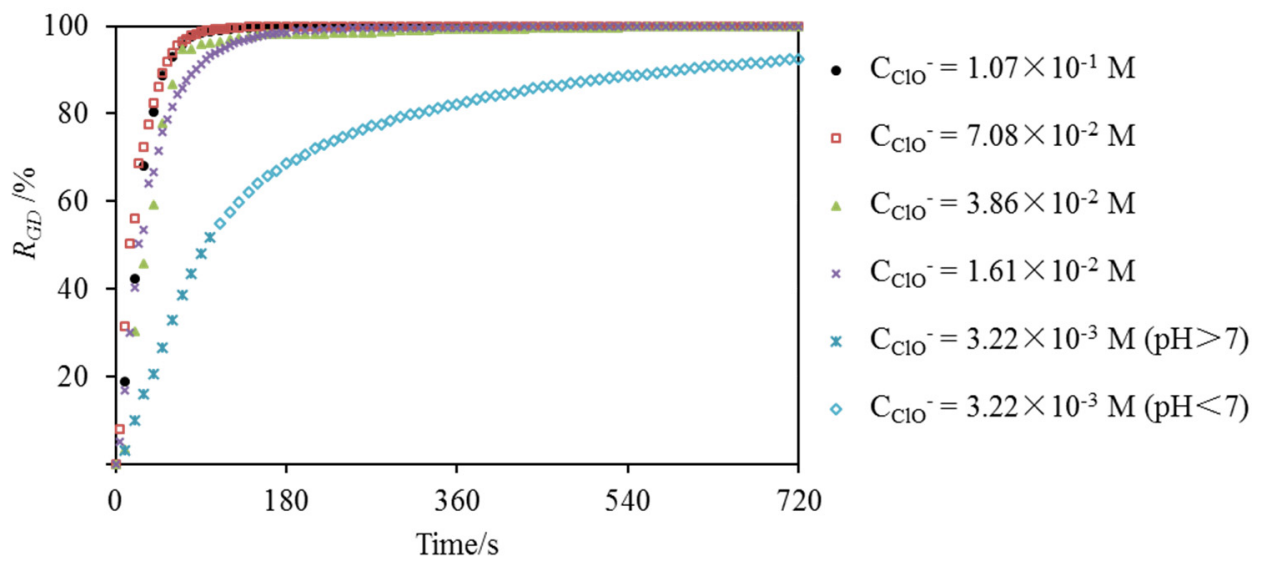

Figure 3 Hydrolysis ratio of $\mathrm{GD}\left(R_{\mathrm{GD}}\right)$ in $\mathrm{NaClO}$ solutions with different $C_{\mathrm{ClO}}{ }^{-}$values $\left(C_{\mathrm{GD}, 0}\right.$ was $\left.4.21 \times 10^{-3} \mathrm{M}\right)$

Table 4. $\mathrm{pH}$ value, $\mathrm{C}_{\mathrm{ClO}^{-}}{ }^{-} \mathrm{COH}^{-}$, and the first-order rate constant of GD hydrolysis in different reaction solutions

\begin{tabular}{cccccc}
\hline Reaction solution & $\mathrm{pH}$ & $\mathrm{C} \mathrm{ClO}^{-}(\mathrm{M})$ & $\mathrm{CoH}^{-}(\mathrm{M})$ & $k_{1}\left(\mathrm{~s}^{-1}\right)$ & $\mathrm{t}_{1 / 2}(\mathrm{~s})$ \\
\hline \multirow{2}{*}{$\mathrm{NaOH}$} & 8.0 & 0 & $1.00 \times 10^{-6}$ & $9.6 \times 10^{-6}$ & 72000.0 \\
& 11.0 & 0 & $9.12 \times 10^{-4}$ & $6.1 \times 10^{-3}$ & 113.6 \\
phosphate buffer $+\mathrm{NaClO}$ & 8.0 & $3.22 \times 10^{-3}$ & $3.02 \times 10^{-6}$ & $8.4 \times 10^{-3}$ & 82.5 \\
& 8.1 & $1.61 \times 10^{-2}$ & $2.09 \times 10^{-6}$ & $3.0 \times 10^{-2}$ & 23.3 \\
& 8.1 & $3.86 \times 10^{-2}$ & $1.66 \times 10^{-6}$ & $4.1 \times 10^{-2}$ & 16.8 \\
& 8.2 & $7.08 \times 10^{-2}$ & $2.69 \times 10^{-6}$ & $4.7 \times 10^{-2}$ & 15.7 \\
\hline
\end{tabular}

$25 \pm 1{ }^{\circ} \mathrm{C} ; C_{\mathrm{GD}, 0}=4.21 \times 10^{-3} \mathrm{M}$. 


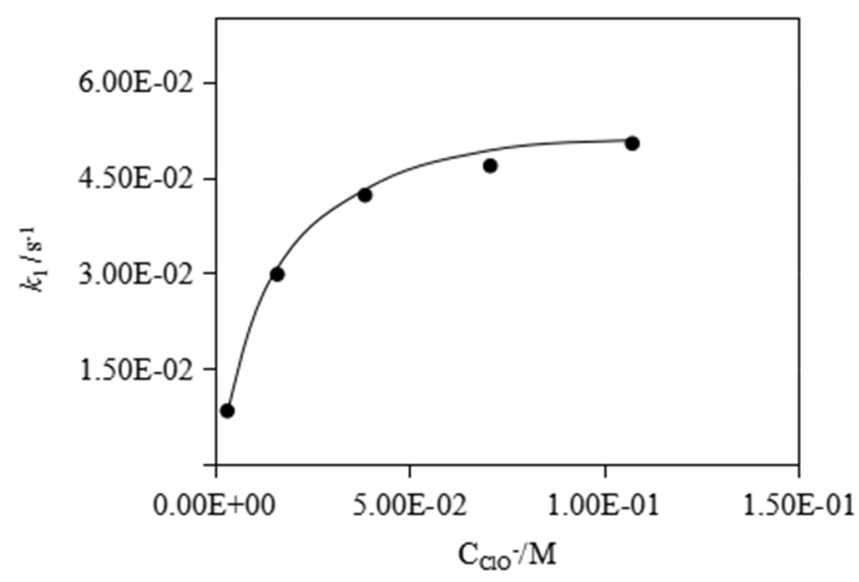

Figure 4 First-order rate constant $\left(k_{1}\right)$ of GD hydrolysis in $\mathrm{NaClO}$ solutions with different $C_{\mathrm{ClO}^{-}}^{-}$values

After the GD hydrolysis reached completion in $\mathrm{NaClO}$ solution at $\mathrm{pH} 8.0$ with $3.22 \times 10^{-3} \mathrm{M} \mathrm{ClO}^{-}$ions, the $C_{\mathrm{ClO}}{ }^{-}$ value of the remaining $\mathrm{NaClO}$ solution was determined to be $3.00 \times 10^{-3} \mathrm{M}$; the decrease in concentration of $\mathrm{ClO}^{-}$ ions was about $2.2 \times 10^{-4} \mathrm{M}$, which is less than $6 \%$ of $C_{\mathrm{GD}, 0}$ $\left(4.21 \times 10^{-3} \mathrm{M}\right)$. This indicates that few $\mathrm{ClO}^{-}$ions were lost during GD hydrolysis. Consequently, it is reasonable to consider that the $\mathrm{ClO}^{-}$ions accelerate GD hydrolysis via a catalysing effect, and the mechanism proposed is as follows. Nucleophilic attack of $\mathrm{ClO}^{-}$ions on the $\mathrm{P}$ atom in GD produces an intermediate product, which would transform into GD acid, with concomitant $\mathrm{HClO}$ formation. Dissociation of $\mathrm{HClO}$ would produce $\mathrm{H}^{+}$and $\mathrm{ClO}^{-} . \mathrm{HClO}$ is unstable in solutions at $\mathrm{pH} 8$, which is a possible reason for the slight decrease in $\mathrm{pH}$ value and the low loss of $\mathrm{ClO}^{-}$ions.<smiles>CC(C)OP(C)(=O)CCC(C)OP(C)(=O)Cl</smiles>

The rate constant for catalysis of GD hydrolysis by $\mathrm{ClO}^{-}$ions $\left(k_{\mathrm{ClO}}^{-}, \mathrm{M}^{-1} \mathrm{~s}^{-1}\right)$ in $\mathrm{NaClO}$ solution at $\mathrm{pH} 8.0$ with a $3.22 \times 10^{-3} \mathrm{M}$ concentration of $\mathrm{ClO}^{-}$could be calculated from equation (7) [9], in which $k_{1}$ was the first-order rate constant of GD hydrolysis in $\mathrm{s}^{-1} ; k_{\mathrm{OH}^{-}}$was the rate constant for the catalysis of GD hydrolysis by $\mathrm{OH}^{-}$in $\mathrm{M}^{-1}$ $\mathrm{s}^{-1}$ (which could be obtained from equation (8) [4] and $\left[\mathrm{OH}^{-}\right]$or $\left[\mathrm{ClO}^{-}\right]$was the concentration of $\mathrm{OH}^{-}$or $\mathrm{ClO}^{-}$in M.

The results are shown in Table 5 , in comparison with those for GD hydrolysis in other solutions. The $k_{\mathrm{ClO}}{ }^{-}$value was about $2.6 \mathrm{M}^{-1} \mathrm{~s}^{-1}$, which is about one quarter of the value of $k_{\mathrm{OH}^{-}}$, whereas it is over 1700 times and 2000 times larger than $k_{\mathrm{B}}$ (the rate constant for catalysis of GD hydrolysis by $\mathrm{B}$, in which $\mathrm{B}$ represents HEPES present as a free base) and $k_{P_{4}^{3-}}$ (the rate constant for catalysis of GD hydrolysis by $\mathrm{PO}_{4}{ }^{3-}$ ), respectively. The results showed that the catalysing effect of $\mathrm{ClO}^{-}$on GD hydrolysis was relatively weaker than that with $\mathrm{OH}^{-}$, but much stronger than those of some other ions. Consequently, GD hydrolysis could be well catalysed by $\mathrm{ClO}^{-}$ions.

$$
\begin{gathered}
k_{\mathrm{ClO}^{-}}=\frac{k_{1-}-k_{\mathrm{OH}^{-}}\left[\mathrm{OH}^{-}\right]}{\left[\mathrm{ClO}^{-}\right]} \\
k_{\mathrm{OH}^{-}}=\frac{k_{1}}{\left[\mathrm{OH}^{-}\right]}
\end{gathered}
$$

Table 5. Rate constant of GD hydrolysis in different reaction solutions $\left(25 \pm 1{ }^{\circ} \mathrm{C}, C_{\mathrm{GD}, 0}=4.21 \times 10^{-3} \mathrm{M}\right)$

\begin{tabular}{ccccc}
\hline Reaction solution & $\mathrm{pH}$ & $\begin{array}{c}\text { Major ion in reaction solution and } \\
\text { its concentration } / \mathrm{M}\end{array}$ & $k_{1} / \mathrm{s}^{-1}$ & $k_{\mathrm{i}} / \mathrm{M}^{-1} \mathrm{~s}^{-1}$ \\
\hline $\mathrm{NaOH}$ & 8.0 & $\mathrm{OH}^{-}, 1.00 \times 10^{-6}$ & $9.6 \times 10^{-6}$ & $9.6\left(i=\mathrm{OH}^{-}\right)$ \\
$\mathrm{NaClO}$ & 8.0 & $\mathrm{ClO}^{-}, 3.22 \times 10^{-3}$ & $8.4 \times 10^{-3}$ & $2.6\left(i=\mathrm{ClO}^{-}\right)$ \\
phosphate buffer & 7.0 & $\mathrm{PO}_{4}^{3-}, 7.66 \times 10^{-2 \mathrm{a}}$ & $9.7 \times 10^{-5}$ & $1.3 \times 10^{-3}\left(i=\mathrm{PO}_{4}{ }^{3-}\right)^{\mathrm{a}}$ \\
HEPES buffer & 7.0 & $\mathrm{~B}, 8.80 \times 10^{-2 \mathrm{~b}}$ & $1.4 \times 10^{-4} \mathrm{~b}$ & $1.5 \times 10^{-3}(i=\mathrm{B})^{\mathrm{b}}$ \\
\hline
\end{tabular}

$\mathrm{a}$ : [9]. b: [10]. $k_{1}$ is the first-order rate constant of GD hydrolysis. $k_{\mathrm{i}}$ is the rate constant for catalysis of GD hydrolysis by different ions. 


\section{Conclusions}

In this study, the impact of hypochlorite $\left(\mathrm{ClO}^{-}\right)$ions on GD hydrolysis was studied. Kinetic experiments were performed to research the GD hydrolysis rate in reaction solutions with different concentrations of $\mathrm{ClO}^{-}$ions. Factors that might affect the speed of GD hydrolysis like the $\mathrm{pH}$ value, temperature and concentration of $\mathrm{ClO}^{-}$ions have been discussed. The rate constants and half-lives of GD hydrolysis in different reaction solutions were calculated, and the catalysing effect of $\mathrm{ClO}^{-}$ions on GD hydrolysis was compared with those of other ions.

The results showed that the $\mathrm{pH}$ value and temperature during our experiments were not main factors that affect GD hydrolysis, whereas the presence of $\mathrm{ClO}^{-}$ions was a critical parameter for accelerating the speed of GD hydrolysis through a catalysing effect. The first-order rate constant $\left(k_{1}\right)$ of GD hydrolysis in $\mathrm{NaClO}$ solution at $\mathrm{pH}$ 8.0 with $3.22 \times 10^{-3} \mathrm{M} \mathrm{ClO}^{-}$ions was $8.4 \times 10^{-3} \mathrm{~s}^{-1}$, which is 875 times larger than that in $\mathrm{NaOH}$ solution at $\mathrm{pH} 8.0$. The higher $C_{\mathrm{ClO}}^{-}$was, the larger $k_{1}$ was, but the increase in $k_{1}$ tended to be gradual. The rate constant for catalysis of GD hydrolysis by $\mathrm{ClO}^{-}$ions $\left(k_{\mathrm{ClO}}^{-}\right)$was $2.6 \mathrm{M}^{-1} \mathrm{~s}^{-1}$, about one quarter that of $k_{\mathrm{OH}^{-}}$, but it was over 1700 times and 2000 times greater than $k_{\mathrm{B}}$ and $k_{\mathrm{PO}_{4}^{3-}}$, respectively (B represents HEPES present as a free base). In conclusion, $\mathrm{ClO}^{-}$ions can catalyse GD hydrolysis well.

\section{References}

1. John, H., Balszuweit F., Steinritz D., Kehe K., Worek F., Thiermann H. (2020) Toxicokinetic aspects of nerve agents and vesicants. In: Handbook of Toxicology of Chemical Warfare Agents, R. C. Gupta (ed.), 3rd edn, Academic Press, London, Chap. 52, 875-919.

2. Epstein J., Bauer V. E., Saxe M., Demek M. M. (1956) The chlorine-catalyzed hydrolysis of isopropyl methylphosphonofluoridate (sarin) in aqueous solution. J. Am. Chem. Soc. 78, 4068-4071.

3. Yang Y. C., Baker J. A., Ward J. R. (1992) Decontamination of chemical warfare agents. Chem. Rev. 92, 1729-1743.

4. Larsson L. (1957) The alkaline hydrolysis of isopropoxy-methylphosphoryl fluoride (sarin) and some analogues. Acta. Chem. Scand. 11, 1131-1142.

5. Epstein J., Cannon P. L., Jr., Sowa J. R. (1970) Catalysis of the hydrolysis of isopropyl methylphosphonofluoridate in aqueous solutions by primary amines. J. Am. Chem. Soc. 92, 7390-7393.

6. Epstein J., Rosenblatt D. H. (1958) Kinetics of some metal ion-catalyzed hydrolyses of isopropyl methylphosphonofluoridate (GB) at $25^{\circ}$. J. Am. Chem. Soc. 80, 3596-3598.

7. Epstein J., Rosenblatt D. H., Demek M. M. (1956) Kinetics of the reaction of isopropyl methylphosphonofluoridate with catechols at $25^{\circ}$. J. Am. Chem. Soc. 78, 341-343.
8. Epstein J., Michel H. O., Rosenblatt D. H., Plapinger R. E., Stephani R. A., Cook E. (1964) Reaction of isopropyl methylphosphonofluoridate with substituted phenols, II . J. Am. Chem. Soc. 86, 49594963.

9. Creasy W. R., Fry R. A., McGarvey D. J. (2012) Reaction of nerve agents with phosphate buffer at $\mathrm{pH}$ 7. J. Phys. Chem. A. 116, 7279-7286.

10. Albizo J. M., Ward J. R. (1991) Soman hydrolysis catalyzed by HEPES buffer. J. Mol. Catal. 66, 191194.

11. Perrin D. D. (1982) 2nd edn, Ionization constants of inorganic acids and bases in aqueous solution. Pergamon Press, Oxford. 